\title{
Spatial variability of meteorological observations and impacts on regional estimates of soybean grain productivity
}

\section{Variabilidade espacial das observações meteorológicas e impactos na estimativa regional da produtividade de soja}

\author{
Rodrigo Cornacini Ferreira ${ }^{1 *}$; Rubson Natal Ribeiro Sibaldelli²; Heverly Morais ${ }^{3}$; \\ Otávio Jorge Grigoli Abi Saab ${ }^{4}$; José Renato Bouças Farias ${ }^{5}$
}

\begin{abstract}
Brazil requires a fully representative weather network station; it is common to use data observed in locations distant from the region of interest. However, few studies have evaluated the efficiency and precision associated with the use of climate data, either estimated or interpolated, from stations far from the agricultural area of interest. Hence, this study aimed to demonstrate the impacts of spatial variability of the main meteorological elements on the regional estimate of soybean productivity. Regression analysis was used to compare data recorded at three weather stations located throughout Londrina, PR, Brazil. The water balance of the soybean crop was calculated at 10-day periods and grain productivity losses estimated using the Agro-Ecological Zones (AEZ) methodology. Temperatures at the three locations were similar, while the relative air humidity, and particularly, the rainfall data, were less correlated. A high degree of caution is recommended in the use and choice of a single weather station to represent a municipality or region, particularly in countries, such as Brazil, with multiple regions of agricultural and environmental importance. Models and crop season estimates that do not consider such a recommendation are vulnerable to errors in their forecasts. The volumetric and temporal variability in the spatial rainfall distribution resulted in soybean yield discrepancies, estimated at the municipal level. The consistency of the data series, the location of weather stations and their distance to the location of interest determine the ability of crop models to accurately estimate soybean production based on meteorological data, particularly the rainfall data. This study contributes to future regional research using climate data, and highlights the importance of a weather station network throughout Brazil, demonstrating the urgent need to increase the number of weather stations, particularly for recording rainfall data.
\end{abstract}

Key words: Glycine $\max$ L. Merrill. Weather station. Rainfall. Climate variability. Agro-ecological zone.

\section{Resumo}

O Brasil ainda não possui uma rede de estações meteorológicas suficientemente representativas, sendo comum a utilização de dados observados em locais distantes da região de interesse. Contudo, são

\footnotetext{
${ }^{1}$ Discente, Curso de Doutorado, Programa de Pós-Graduação em Agronomia, Universidade Estadual de Londrina, UEL, Centro de Ciências Agrárias, Departamento de Agronomia, Londrina, PR, Brasil. E-mail: agrorcf@gmail.com

2 Discente, Curso de Mestrado do Programa de Pós-Graduação em Engenharia Ambiental, Universidade Tecnológica Federal do Paraná, UTFPR, Londrina, PR, Brasil. E-mail: rubson.natal@gmail.com

${ }^{3}$ Enga $^{\text {a }}$ grr $^{\text {a }}$, Dr ${ }^{\text {a }}$, Pesquisadora, Instituto Agronômico do Paraná, IAPAR, Londrina, PR, Brasil. E-mail: heverly@iapar.br

${ }^{4}$ Eng $^{\text {O Agro }}$, Prof. Dr., Departamento de Agronomia, CCA, UEL, Londrina, PR, Brasil. E-mail: abisaab@uel.br

${ }^{5}$ Eng $^{\circ}$ Agr $^{\circ}$, Dr., Pesquisador, Empresa Brasileira de Pesquisa Agropecuária, EMBRAPA Soja, Londrina, PR, Brasil. E-mail: joserenato.farias@embrapa.br

* Author for correspondence
} 
escassos estudos que avaliem a eficácia e precisão da utilização de dados climáticos estimados ou interpolados a partir de estações distantes da área agrícola de interesse. Assim, este estudo teve como objetivo demonstrar os impactos da variabilidade espacial dos principais elementos meteorológicos sobre a estimativa regional da produtividade de grãos de soja. Utilizaram-se dados observados em três estações meteorológicas em diferentes locais de Londrina, comparados por meio de análise de regressão. Calculou-se o balanço hídrico decendial para soja e estimaram-se as perdas de produtividade de grãos pelo método Zona Agroecológica. As temperaturas nos diferentes locais apresentaram semelhanças, enquanto a umidade relativa do ar e, principalmente, precipitação pluvial foram mais discrepantes. Recomenda-se muita cautela no uso e na escolha de uma única estação meteorológica para representar um município ou região, como acontece em várias regiões de importância agrícola e ambiental no Brasil. Modelos e resultados de estimativas de safras que não consideram tal recomendação estão vulneráveis a erros em suas previsões. A variabilidade volumétrica e temporal na distribuição espacial das precipitações pluviais provocaram diferentes estimativas de produtividade de soja em escala municipal. A consistência da série de dados, a localização das estações meteorológicas e a distância destas ao ponto de interesse são fatores determinantes da precisão em modelos para estimativas da produtividade de grãos de soja com base em dados meteorológicos, com destaque para a precipitação pluvial. Este estudo contribui para futuras pesquisas regionais que utilizem dados climáticos, além de evidenciar a importância da rede de estações meteorológicas em todo Brasil, demonstrando a necessidade urgente do incremento no número dessas estações, em especial para o registro de dados das precipitações pluviais. Palavras-chave: Glycine $\max$ L. Merrill. Estação meteorológica. Precipitação pluvial. Variabilidade climática. Zona agroecológica.

\section{Introduction}

High-quality and long-term meteorological data records are essential for generalized multidisciplinary applications, particularly farm management, a high-risk economic activity due to its direct climate dependence. Variations in plant behavior and crop productivity can be due to variability in the occurrence of climate elements, leading to major social, environmental and economic impacts (SIVAKUMAR et al., 2000; VIVAN et al., 2015).

Climate-related economic losses, including drought, have increased in the last decades (CEDA, 2014). In a study for the Brazilian Planning Ministry at the end of the twentieth century Göpfert et al. (1993) observed that drought was the main cause of agricultural claims ( $71 \%$ of cases). Since 2007, almost all crop insurance has received grants (MAIA et al., 2011).

Water plays an important role in plants. Indeed, water availability is one of the main factors responsible for crop yield variability in space and time (FARIAS et al., 2001). In soybean, water deficit during germination-emergence and flowering-grain filling can lead to a substantial decrease in yield and grain production (EMBRAPA, 2013).

Implementing some of the technological advances available in climate data usage and information, would provide an enhanced weather station network in Brazil. For example, the Brazilian central region is the main soybean producer but it has a very limited number of efficient weather stations (FERNANDES et al., 2012).

To represent the spatial distribution of meteorological elements, or even variables derived from their application, several authors have used interpolation techniques for spatialization in large areas (CECÍlIO et al,. 2012; CARVALHO et al., 2012; ASHRAF et al., 2013). Due to limited meteorological element information or gaps in weather data recorded at different Brazilian locations, essential variables have frequently been estimated and interpolated (ANDRADE et al., 2012).

Mathematic models of crop yields can evaluate the regional impact of climate variability risks associated with agricultural production (TSUKAHARA et al., 2008; ANGULO et al., 2013; 
MONTEIRO; SENTELHAS, 2014; VIANNA; SENTELHAS, 2014; VIVAN et al., 2015). Although increasingly more precise, the application of these models has been criticized due to the scarcity of climate information with high spatial resolution enabling high accuracy and coverage (ANGULO et al., 2013).

Brazil lacks studies that evaluate the efficiency and precision regarding the use of climate data estimated or interpolated from weather stations far from the agricultural area of interest. In face of the limitations presented, this study aimed to demonstrate the impacts of spatial variability of the main meteorological elements on the regional estimate of soybean grain yield.

\section{Material and Methods}

The study area corresponded to the geographic limits of Londrina, municipality located in northern Paraná State, South Region of Brazil. According to the Köppen classification, the climate is Cfa, humid subtropical, with mean air temperature below $18^{\circ} \mathrm{C}$ during the coldest months and above $22^{\circ} \mathrm{C}$ during the hottest months, with hot summers, occasional frost, and rainfall mostly during summer months, but with no dry season defined (ALVARES et al., 2012, 2013).

The meteorological data used in this study were recorded by three weather stations belonging to research institutes located in Londrina, i.e. Brazilian Agricultural Research Corporation - Embrapa Soybean (EMBRAPA), located at $23^{\circ} 11^{\prime} \mathrm{S}$, $51^{\circ} 11^{\prime} \mathrm{W}$ and $630 \mathrm{~m}$ altitude; Agronomic Institute of Paraná (IAPAR, located at $23^{\circ} 22^{\prime} \mathrm{S}, 51^{\circ} 10^{\prime} \mathrm{W}$ and $585 \mathrm{~m}$ altitude; National Institute of Meteorology (INMET), located at $23^{\circ} 19^{\prime} \mathrm{S}, 51^{\circ} 8^{\prime} \mathrm{W}$ and $566 \mathrm{~m}$ altitude. The EMBRAPA weather station is 18.4 and $15.2 \mathrm{~km}$ away from stations IAPAR and INMET, respectively, and the distance between stations IAPAR and INMET is $4.4 \mathrm{~km}$ (Figure 1).
The study used a historical series of daily weather records spanning 23 years (1 Jan 1991-31 Dec 2013). The meteorological elements analyzed were: mean, maximum and minimum air temperature $\left({ }^{\circ} \mathrm{C}\right)$; mean relative air humidity (\%) and accumulated rainfall $(\mathrm{mm})$. The correlations between these elements for each weather station was determined through regression analysis (PEREIRA et al., 2008), with the intersection passing through the origin $(\alpha=0)$. The angular coefficient $(b)$ was used to measure the accuracy, while the coefficient of determination $\left(R^{2}\right)$ was considered a precision measurement. Thus, if the resultant value of a meteorological element is the same in different locations, the result would be in $b=1$ and $R^{2}=1$ (SENTELHAS et al., 2010).

The water balance for soybean crop was calculated at 10-day periods according to the method proposed by Thornthwaite and Mather (1955), using spreadsheets. We considered soybean cultivars with a ripening cycle of 120 days, divided into four phenological phases, which were evaluated (FARIAS et al., 2001) and adapted to this study as shown in Table 1.

Yield was estimated for 2011/12, 2012/13 and 2013/14 crop seasons. These time sequences were chosen based on their differentiated climate conditions and crop productivity in the region studied. The sowing dates were the same for the three crop seasons, occurring within the first 10day period of November, due to comparable soil type and crop management for the three regions represented by weather stations.

Due to the soil management practices used in the region studied, which favored the root system development, a value of $75 \mathrm{~mm}$ was adopted as the available water capacity in the soil (CAD). The resultant values of reference evapotranspiration (ETo) were multiplied by the crop coefficient (Kc) specific for each phenological phase (Farias et al., 2001), as described in Table 1, thus obtaining the crop evapotranspiration (ETc). 
Figure 1. Altimetry map of Londrina, highlighting the urban land occupation and geographical location of weather stations Embrapa Soybean (EMBRAPA), Agronomic Institute of Paraná (IAPAR), and National Institute of Meteorology (INMET).

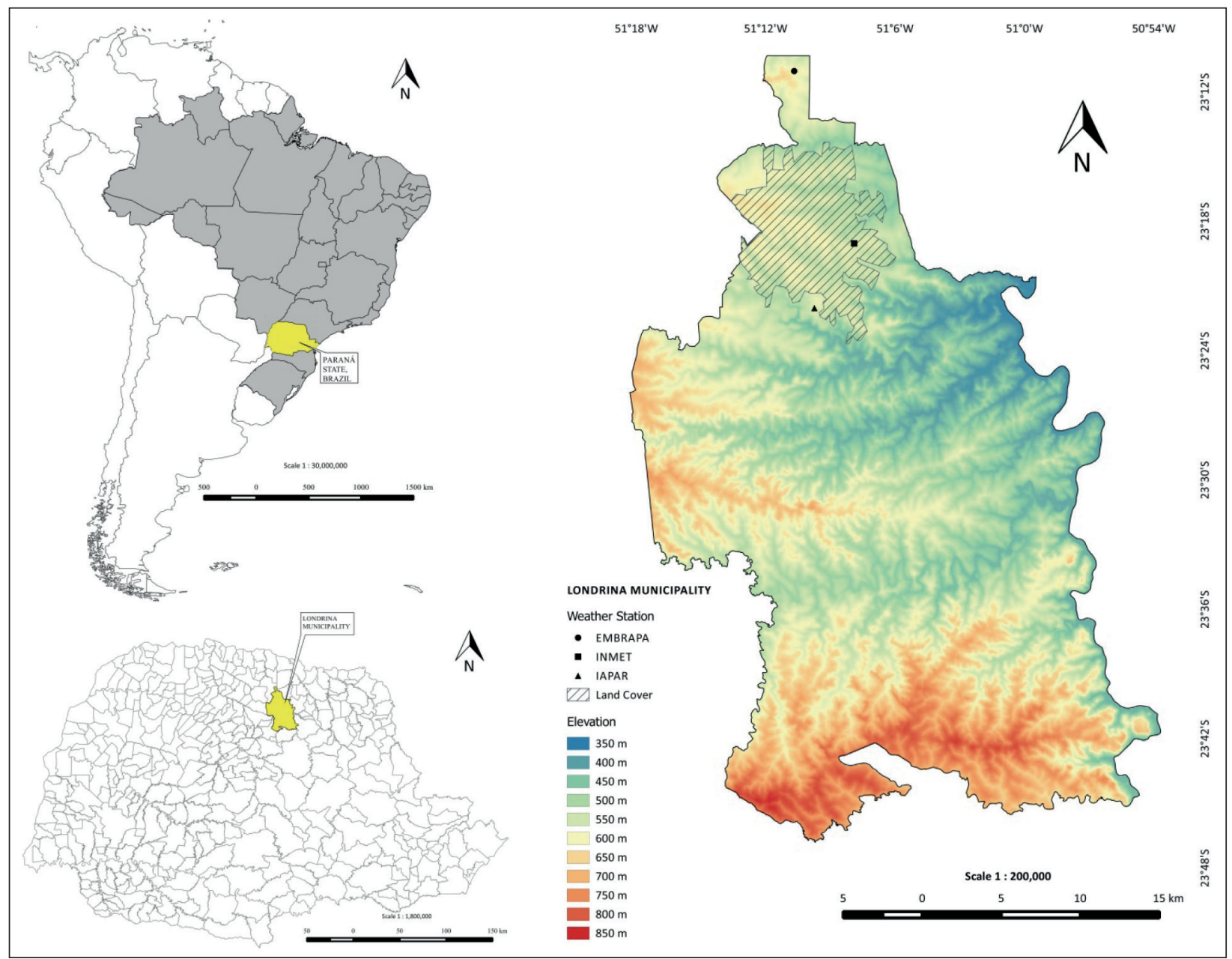

Table 1. Duration of phenological stages of soybean crop with cycle of 120 days and their respective crop coefficient $(\mathrm{Kc})$ and water deficit sensitivity index (Ky).

\begin{tabular}{lcccc}
\hline & S-V2 & V2-R1 & R1-R5/R6 & R6/R8 \\
\hline Days & 10 & 40 & 40 & 30 \\
Kc (FARIAS et al., 2001) & 0.56 & 1.21 & 1.50 & 0.90 \\
Ky (DOORENBOS; KASSAM, 1994) & 1.00 & 0.20 & 0.80 & 1.00 \\
\hline
\end{tabular}

S: sowing; V2: leaf developed on the first node above the unifoliate leaf; R1: onset of flowering; R5: pod containing $3 \mathrm{~mm}$ grains in one of the four superior nodes with developed leaves; R6: pod containing fully developed grains in one of the four superior nodes with developed leaves, R8: full ripeness.

The potential yield(Yp), was estimated according to the Agroecological Zone (AEZ) methodology (DOORENBOS; KASSAM, 1994). Thus, Yp was obtained according to equation (1):

$$
Y p=\left(\frac{G P * C_{L A I^{*}} C_{R} * C_{H} * N D}{1-(0.01 * C w)}\right)
$$

where, GP is gross photosynthesis in $\mathrm{kg} \mathrm{ha}^{-1}$ day $^{-1}$ of a standard crop with leaf area index (LAI) equal 
to 5; $\mathrm{C}_{\mathrm{LAI}}$, correction for LAI; $\mathrm{C}_{\mathrm{R}}$, the depletion coefficient associated with the maintenance respiration; $\mathrm{C}_{\mathrm{H}}$, crop harvested index; $\mathrm{ND}$, number of days of the period; and $\mathrm{C}_{\mathrm{w}}$, the water content in the harvested part of the plant.

The GP is the sum of standard potential yields for periods of clear sky (GPc) and overcast sky (GPo), as shown in equations (2) and (3):

$$
\begin{gathered}
G P C=\left\{[107.2+(0.36 * \text { Ro })] * c T c * \frac{n}{N}\right\} \\
G P o=\left\{[31.7+(0.219 * \text { Ro })] * c T n *\left(1-\frac{n}{N}\right)\right\}
\end{gathered}
$$

where, Ro is the extraterrestrial solar radiation in cal $\mathrm{cm}^{-2}$ day $^{-1}$; cTc and $\mathrm{cTn}$ are correction factors for air temperature during days of clear and cloudy sky, respectively; $n$ is the daily insolation in hours per day; and $\mathrm{N}$ is the number of hours regarding maximum daily sunshine. The $\mathrm{C}_{\mathrm{LAI}}$ was calculated according to equation (4) (BATTISTI et al., 2013):

$\left.C_{L A I}=\left[0.0093+\left(0.185 * L A I_{M A X}\right)-\left(0.0175 * L A I_{M A X}{ }^{2}\right)\right]\right]$

where the maximum LAI for soybean was considered 4.5. For $\mathrm{C}_{\mathrm{R}}$, the value of 0.5 was adopted; for $\mathrm{C}_{\mathrm{H}}$, 0.35; and for $\mathrm{C}_{\mathrm{w}}, 13 \%$ (BATTISTI et al., 2013).

Attainable yield (Ya) was estimated by imposing a water deficit penalty on the potential yield (Yp) obtained, according to equation (5):

$$
Y a=\left\{1-\left[K y *\left(1-\frac{E T r}{E T c}\right)\right]\right\} * Y p
$$

where the real evapotranspiration of crop (ETr) values were obtained through water balance calculation (THORNTHWAITE; MATHER, 1955) for each phase. The values of water deficit sensitivity index (Ky) adopted in each phase (DOORENBOS; KASSAM, 1994) are shown in Table 1. Yield losses due to water deficit (YLWD) were calculated according to equation (6):

$$
Y L W D(\%)=\left[1-\left(\frac{Y a}{Y p}\right)\right] * 100
$$

\section{Results and Discussion}

The regression analysis regarding weather stations for air temperature (mean, maximum and minimum), with intersection passing through the origin $(\mathrm{y}=b \mathrm{x})$, showed angular coefficients $(b)$ ranged from 0.9782 to 1.0582 , while coefficients of determination $\left(R^{2}\right)$ ranged between 0.8347 and 0.9785 , indicating high correlation among the three locations (Figure 2). Similar results were described for mean, maximum and minimum temperatures in northern Paraná (SOUZA et al., 2003; PEREIRA et al., 2008).

The mean and maximum temperatures were less correlated among the locations relative to minimum temperatures (Figure 2). The weather stations, IAPAR and INMET, were the most similar regarding all temperatures, with $R^{2}$ ranging from 0.9463 to 0.9785 , which could be due to the proximity of the locations and similar altitudes. The regression analysis between the stations EMBRAPA and INMET showed $R^{2}$ ranged from 0.8347 to 0.9242 for all temperatures, indicating less correlation between the values recorded at these locations.

As shown in Figure 2, the angular coefficients for INMET ranged between 1.0213 and 1.0582, indicating higher mean and maximum temperatures recorded at this station compared to EMBRAPA and IAPAR. This could be related to its location, being in an urban area. The angular coefficients 0.9782 and 0.9985 indicated higher minimum temperatures for the EMBRAPA station relative to INMET and IAPAR. However, EMBRAPA also showed high data variability, with $R^{2}$ values between 0.8347 and 0.8413 . 
Figure 2. Regression analysis, with linear coefficient passing through the origin, between the weather stations Embrapa Soybean (EMBRAPA), Agronomic Institute of Paraná (IAPAR), and National Institute of Meteorology (INMET). Daily data of mean (A), maximum (B) and minimum (C) air temperatures. Londrina, PR, Brazil, 1991-2013.

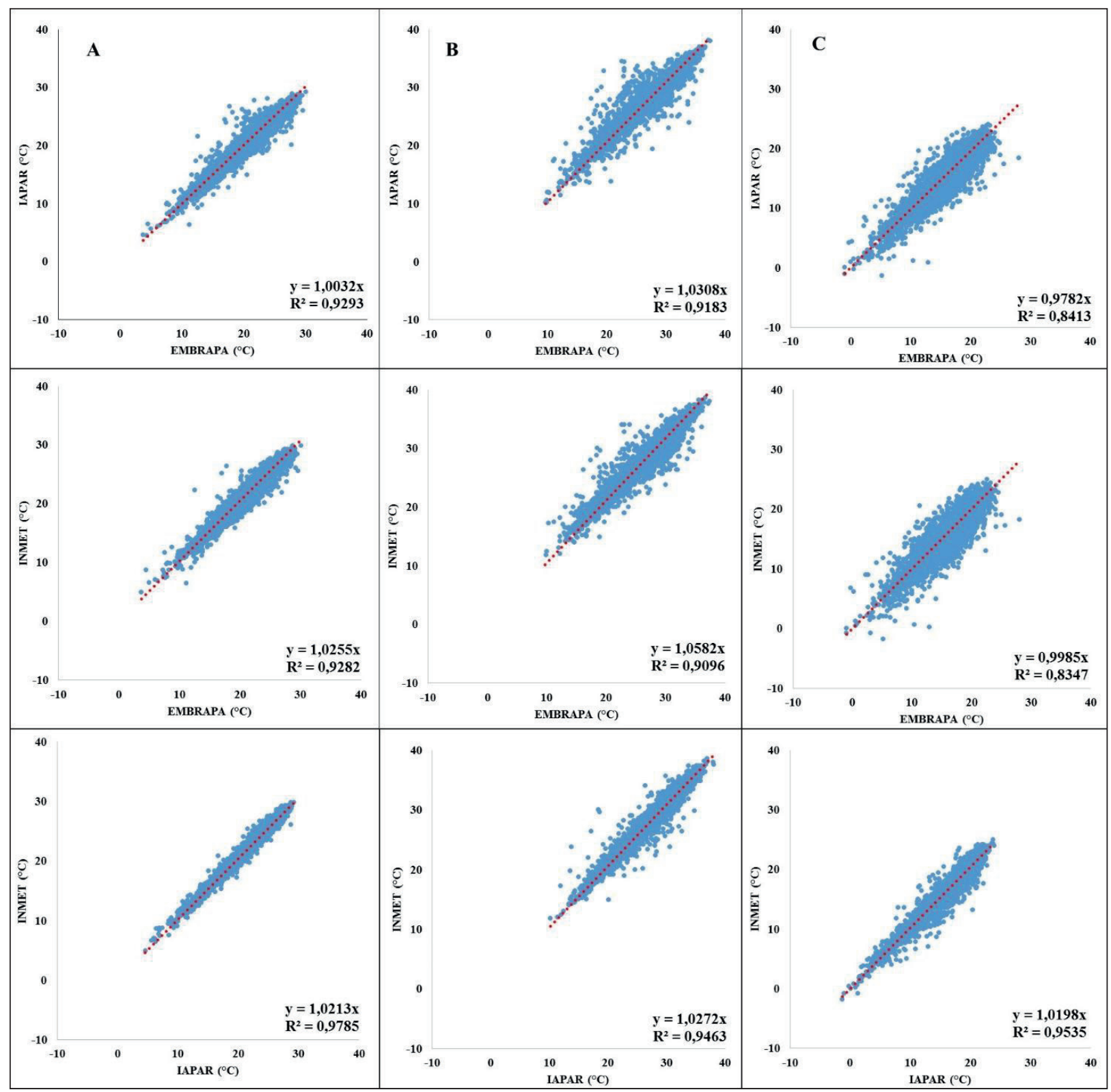

For relative air humidity, the angular coefficients ranged from 0.9319 to 1.0544 , with higher values for the EMBRAPA station relative to INMET (0.9732) and IAPAR (0.9319), respectively (Figure $3 \mathrm{~A})$. Furthermore, the INMET station showed higher values relative to IAPAR (1.0544). $R^{2}$ values ranged from 0.2752 to 0.7232 , indicating high variability among the weather stations. The INMET station presented lower $R^{2}$ values relative to those of EMBRAPA (0.2752) and IAPAR (0.6561). The EMBRAPA station showed $R^{2}$ equal to 0.7232 relative to IAPAR.

The relative air humidity at INMET station was more variable compared to EMBRAPA and IAPAR. The inconsistencies in the data recorded at this weather station compared to the other two suggests 
a need for further investigations at the station. In Maringá, a municipality $90 \mathrm{~km}$ from Londrina, relative air humidity data recorded in different locations also showed low correlation among the weather stations (SOUZA et al., 2003; PEREIRA et al., 2008).

Figure 3. Regression analysis, with linear coefficient passing through the origin, between the weather stations Embrapa Soybean (EMBRAPA), Agronomic Institute of Paraná (IAPAR), and National Institute of Meteorology (INMET). Daily relative air humidity (A), daily accumulated rainfall (B), and rainfall accumulated between October and March (C). Londrina, PR, Brazil, 1991-2013.

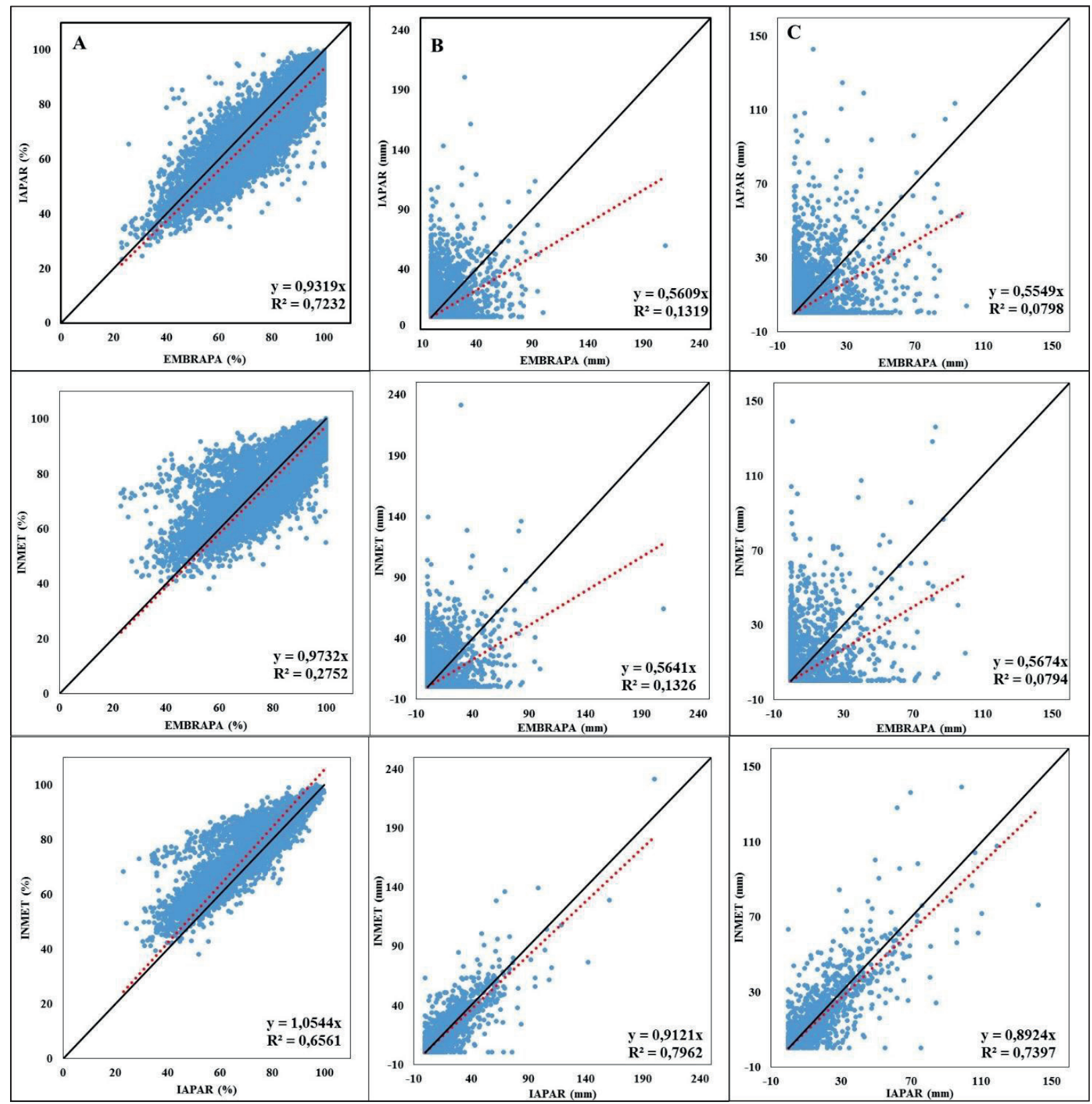

The daily rainfall results indicated high spatial, at EMBRAPA station showed high variability temporal and volumetric variability, even at a compared with INMET $\left(R^{2}=0.1326 ; b=0.5641\right)$ municipal level (Figure 3B). The data recorded and IAPAR $\left(R^{2}=0.1319 ; b=0.5609\right)$. Despite 
the high spatial variability, the EMBRAPA station had more daily rainfall relative to the others. The locations closest together (INMET and IAPAR) were more interrelated, with $R^{2}$ of 0.7962 and angular coefficient 0.9121. Similarly, several previous authors have found high temporal and spatial variabilities in rainfall distribution (CAMARGO et al., 2005; BRITTO et al., 2008; ASHRAF et al., 2013).

Figure 3C shows the regression analysis among weather stations on daily rainfall data accumulated from October to March, comprising the soybean crop season. The data from EMBRAPA station showed greater variability than those of INMET $\left(R^{2}\right.$ $=0.0794 ; b=0.5674$ and IAPAR $\left(R^{2}=0.5549 ; b=\right.$ $0.0798)$, but, as seen in Figure $3 \mathrm{~B}$ this station also had more daily rainfall during the crop season than the others. The locations closest together (INMET and IAPAR) were also more interrelated during the crop season period, with $R^{2}$ of 0.7397 and angular coefficient 0.8924 .

The accumulated monthly volume and distribution of rainfall recorded by the weather stations between 1991 and 2013 is shown in Figure 4. The mean annual rainfall accumulated over this period was 1,398.8 $\mathrm{mm}$ (EMBRAPA); 1,613.4 $\mathrm{mm}$ (IAPAR); and $1,599.5 \mathrm{~mm}$ (INMET). The total rainfall accumulated over the 23 years was $32,171.3 \mathrm{~mm}$ and $37,107.7 \mathrm{~mm}$ in the weather stations EMBRAPA and IAPAR, respectively, and the accumulated difference was $4,936.4 \mathrm{~mm}$, with annual mean of $214.6 \mathrm{~mm}$.

Figure 4. Distribution of mean monthly accumulated rainfall (bars) and number of rainy days (lines) between 1991 and 2013 recorded at the weather stations Embrapa Soybean (EMBRAPA), Agronomic Institute of Paraná (IAPAR) and National Institute of Meteorology (INMET), in Londrina, PR, Brazil.

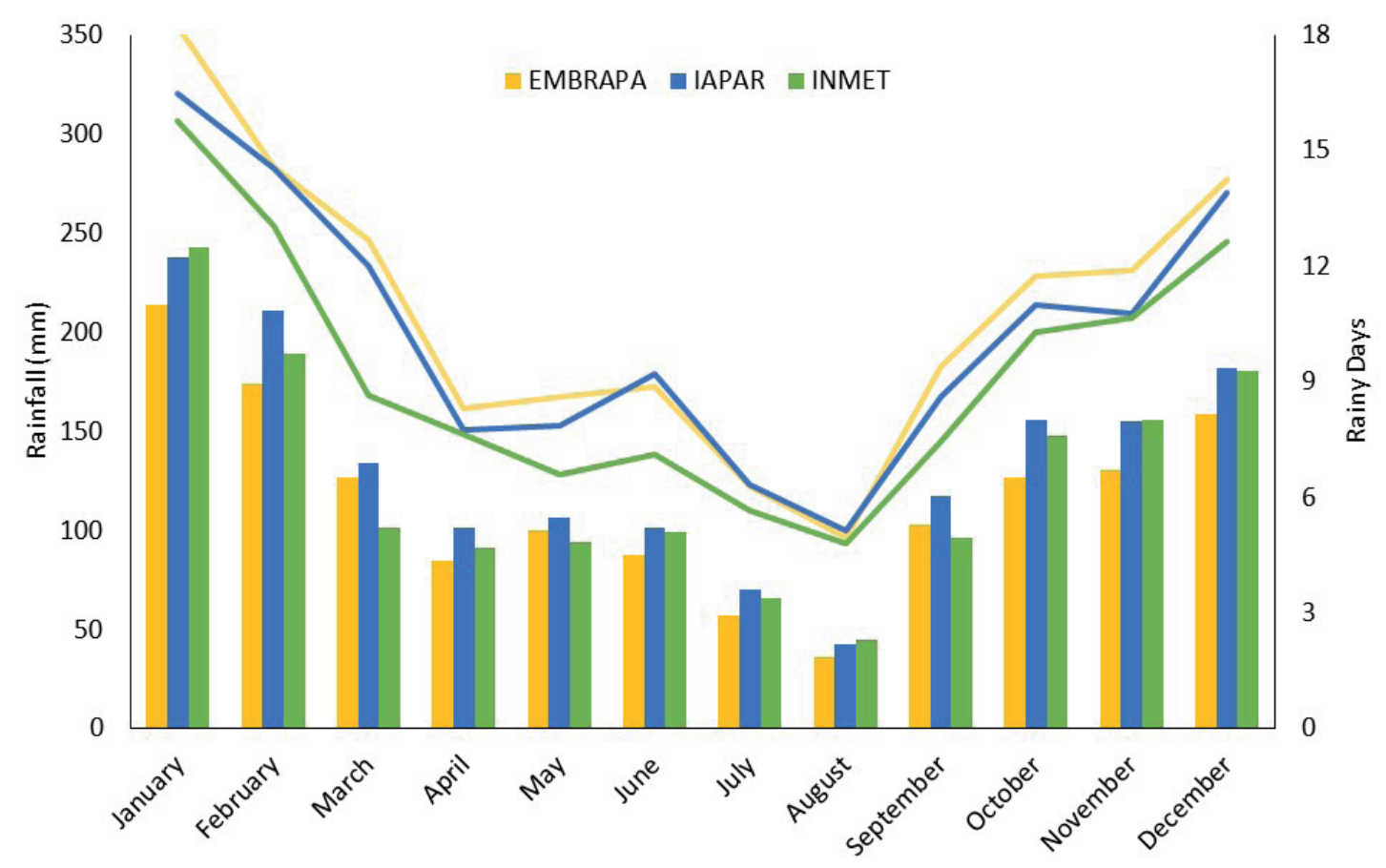

In general, the rainfall distribution across the three stations showed the EMBRAPA station had more frequent rainy days throughout the year than stations IAPAR and INMET (Figure 4). However, in June, the driest month, rainfall distributions of stations EMBRAPA and IAPAR were similar, and in August no marked difference between the three weather stations was observed. The INMET station recorded the lowest number of rainy days throughout the year. Although the EMBRAPA 
station had more frequent rainfall its total rainfall volume was lower than that of IAPAR irrespective of the month (Figure 4).

With the exception of March, May and September, INMET station recorded a greater rainfall volume than EMBRAPA, but with fewer rainy days. This suggests the occurrence of extreme rainfall in urban areas, i.e. high intensities, especially in the rainy months, such as December and January.

The accumulated mean daily rainfall recorded by the station EMBRAPA was $3.8 \mathrm{~mm}$, while INMET recorded $4.4 \mathrm{~mm}$, an increase of $15.8 \%$. The mean yearly rainfall accumulation at INMET $(1,599.5$ $\mathrm{mm})$ was similar to that of IAPAR $(1573.39 \mathrm{~mm})$. In a study involving the weather station network of the Agronomic Institute of Campinas (IAC), located in São Paulo State (Brazil), 19 weather stations were analyzed, and the greater the distances among stations, the higher the standard error values, according to the meteorological element analyzed and the year (CAMARGO et al., 2005).

During spring and summer in Southern Brazil, from October to March, the mean rainfall accumulated over 23 years was 929; 1,073 and 1,093 $\mathrm{mm}$ in the weather stations EMBRAPA, IAPAR and INMET, respectively. The data corroborated the climate classification of the Londrina Region as Cfa, with rainfall occurring mostly during the summer months (ALVARES et al., 2013).

Comparing rainfall between EMBRAPA and IAPAR, EMBRAPA and INMET, and IAPAR and INMET, the differences between the total accumulated from October to March were $3.1 \mathrm{~mm}$, $-59.2 \mathrm{~mm}$, and $-62.3 \mathrm{~mm}$, respectively, for the crop season 2011/12. For the same duration, these values were $-160.6 \mathrm{~mm},-76.2 \mathrm{~mm}$, and $84.4 \mathrm{~mm}$ for the crop season 2012/13, and -111.4 mm, $-167 \mathrm{~mm}$, and $-55,6 \mathrm{~mm}$ for the crop season $2013 / 14$, respectively.

Water balance of the soybean crop during seasons 2011/12, 2012/13, and 2013/14 are shown in Figure 5. Although the simulated sowing date was the same for all three weather stations, water deficit and surplus periods were different with respect to intensity and time of occurrence, which confirmed the variability of rainfall occurrences within the municipality.

The estimated soybean grain yield losses due to water deficit are shown in Figure 6, i.e. $41.5 \%$ (EMBRAPA), 45.3\% (IAPAR), and 47.6\% (INMET) in the crop season 2011/12. Water deficit was lower in the subsequent crop season, 2012/13, and yield losses were $7.8 \%$ (EMBRAPA), 9\% (IAPAR), and $12.6 \%$ (INMET). In the crop season 2013/14, the values were $85.1 \%$ (EMBRAPA), 57.3\% (IAPAR), and $68.4 \%$ (INMET). Such results corroborated previous studies in which water availability was considered one of the main factors responsible for crop yield variability, in space and time (FARIAS et al., 2001; BATTISTI et al., 2013; MATESE et al., 2014; VIVAN et al., 2015).

The 2012/13 crop season led to the lowest estimate of yield loss due to water deficit. When compared to the previous and the subsequent season, it showed the highest accumulated rainfall volume for all three stations (Table 2). This result corroborates studies in which the total water requirements range from 450 to $800 \mathrm{~mm} /$ cycle to obtain a maximum soybean crop yield, depending on climate conditions, crop management and cycle duration (EMBRAPA, 2013).

In general, the crop season 2012/13 was considered favorable regarding rainfall occurrence for soybean crop in Londrina. However, among the weather stations, a small variation in water amount and availability on the soybean grain phenological stages V2-R1 (Figures 4D; 4E; 4F) affected the soybean grain yield in different municipal locations (Figure 6). At $15.2 \mathrm{~km}$ distance between the weather stations of southern (INMET) and northern (EMBRAPA) regions of Londrina, there was a $4.8 \%$ difference between the estimated soybean grain yield losses in that crop season, with greater loss in the southern region. 
Figure 5. Water balance of soybean crop at 10 -day periods from November $1^{\text {st }}$ to February $28^{\text {th }}$ during $2011 / 12$ [EMBRAPA=(A); IAPAR=(B); INMET=(C)], 2012/13 [EMBRAPA=(D); IAPAR=(E); INMET=(F)], and 2013/14 $[$ EMBRAPA $=(\mathrm{G}) ; \mathrm{IAPAR}=(\mathrm{H})$; INMET $=(\mathrm{I})]$ crop seasons. Values of water surplus $(\mathrm{SUR})$, deficit $(\mathrm{DEF})$, withdrawal (WIT) and replacement (REP) from the weather stations Embrapa Soybean (EMBRAPA), Agronomic Institute of Paraná (IAPAR) and National Institute of Meteorology (INMET), in Londrina, PR, Brazil.
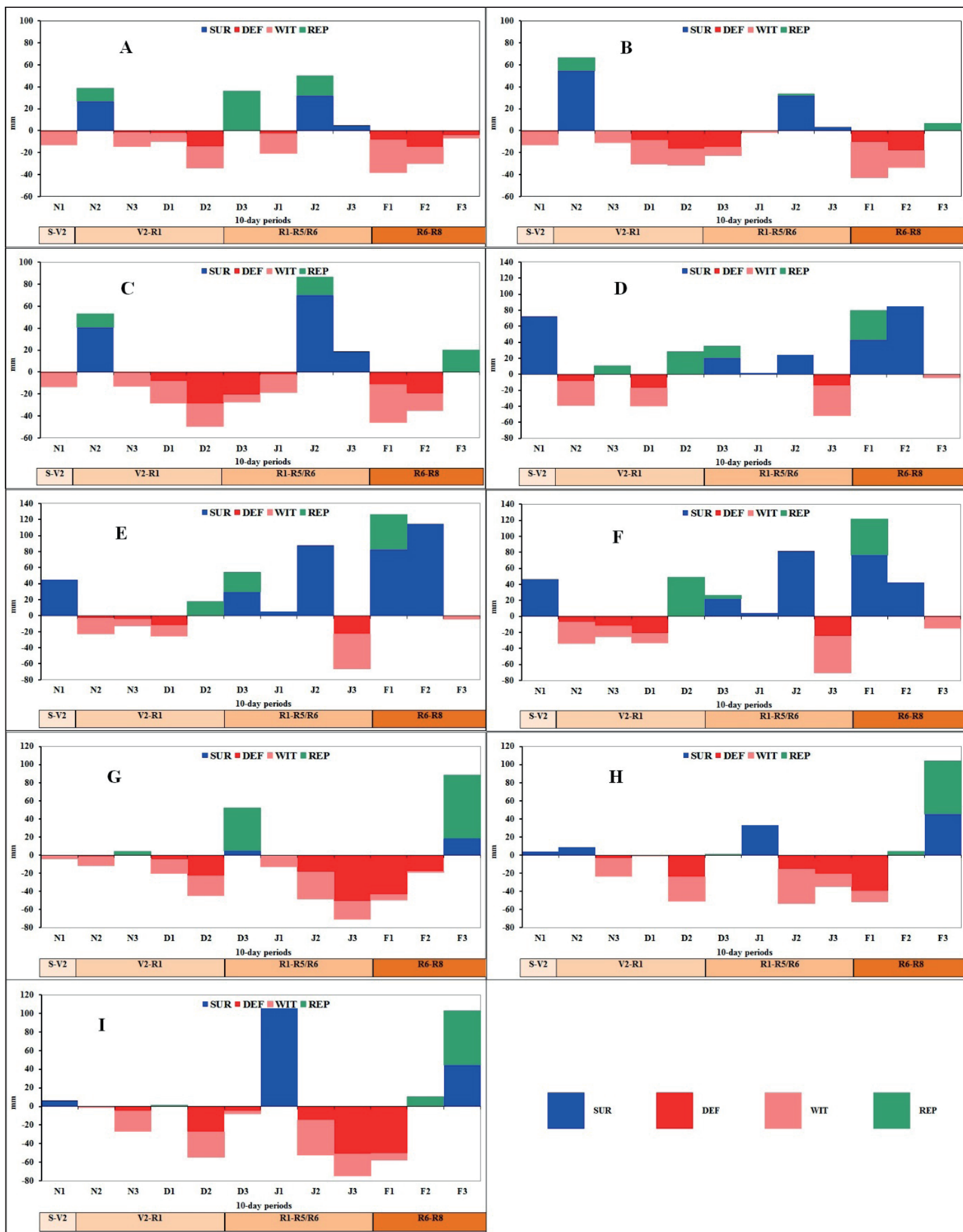
Figure 6. Estimates of drought-induced soybean grain yield losses for the crop seasons 2011/12, 2012/13, and 2013/14, in the weather stations Embrapa Soybean (EMBRAPA), Agronomic Institute of Paraná (IAPAR) and National Institute of Meteorology (INMET), in Londrina, PR, Brazil.

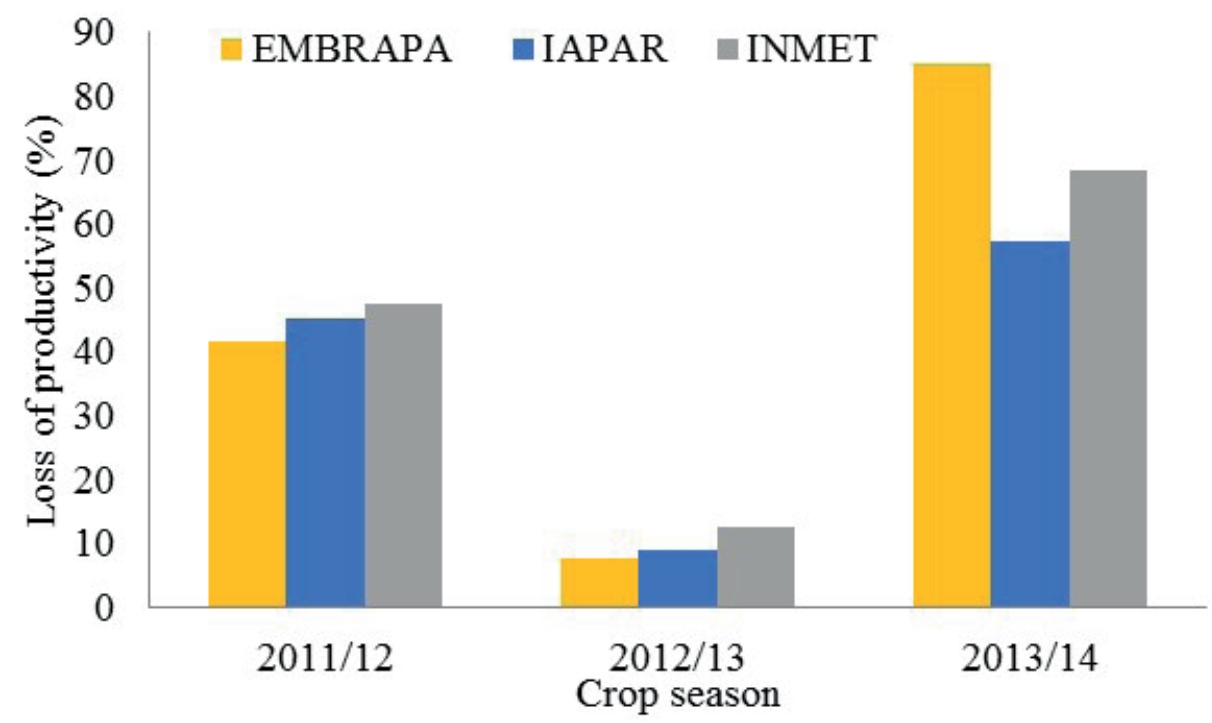

Table 2. Accumulated rainfall $(\mathrm{mm})$ recorded by the weather stations Embrapa Soybean (EMBRAPA), Agronomic Institute of Paraná (IAPAR) and National Institute of Meteorology (INMET), during the crop seasons 2011/12, 2012/13 and 2013/14, in Londrina, PR, Brazil.

\begin{tabular}{cccc}
\hline \multirow{2}{*}{ Weather stations } & \multicolumn{3}{c}{ Accumulated rainfall $(\mathbf{m m})$ during crop season } \\
\cline { 2 - 4 } & $\mathbf{2 0 1 1 / 1 2}$ & $\mathbf{2 0 1 2} / \mathbf{1 3}$ & $\mathbf{2 0 1 3} / \mathbf{1 4}$ \\
\hline EMBRAPA & 468.9 & 722.9 & 431.2 \\
IAPAR & 465.8 & 883.5 & 542.6 \\
INMET & 528.1 & 799.1 & 598.2 \\
\hline
\end{tabular}

Among the crop seasons analyzed, the 2013/14 yields were most affected by the rainfall variability and the consequent water deficit in Londrina (Figures 4G; 4H; 4I). The EMBRAPA station showed the greatest yield losses, despite an accumulated rainfall volume of $431.2 \mathrm{~mm}$ in that crop season, which is below the minimum requirement for soybean crop (EMBRAPA, 2013). In 2013/14, the longest period of water deficit occurred at the onsets of grain filling and unripe greens (Figure 6), which are considered critical periods regarding water deficit. In these growth phases, drought can drastically reduce the crop yield (EMBRAPA, 2013).

There were differences between the rainfall volume accumulated during 2013/14 and 2011/12 crop seasons (Table 2), with higher water availability recorded at the IAPAR $(542.6 \mathrm{~mm} ; 465.8 \mathrm{~mm}$, respectively) and INMET $(598.2 \mathrm{~mm} ; 528.1 \mathrm{~mm}$, respectively) stations. Thus, even with higher water volume during the 2013/14 compared to 2011/12 crop season at stations IAPAR and INMET, such a fact did not represent lack of yield losses due to water deficit. This demonstrated that the rainfall distribution was directly responsible for soybean yield variability among the different regions, within the studied municipality (Figures 4H; 4I).

In the crop season 2013/14, the EMBRAPA station was the most affected by water deficit, with $85.1 \%$ yield losses (Figure 6). On the first 10-day period of January, soil water withdrawal occurred, resulting in a water deficit for soybean crop from the second 10-day period of January until the 
second 10-day period of February (Figure 5G). This corresponds to the grain-filling stage of the soybean crop (R5/R6), which is considered a critical period for yield (FARIAS et al., 2001; EMBRAPA, 2013). There were also high yield losses at stations INMET (68.41\%) and IAPAR (57.29\%) due to water deficit. These losses were minimized by the rainfall volume, as recorded on the first 10-day period of January, which increased the amount of soil water available for the soybean crop.

The use and choice of a single weather station to represent a municipality or region necessitates a degree of caution, particularly in regions of agricultural and environmental importance. Models and results of crop season estimates that do not consider such a recommendation are vulnerable to errors in their forecasts.

\section{Conclusions}

Rainfall was the meteorological element presenting the highest variability among the locations studied. The volumetric and temporal variability in the spatial rainfall distribution led to different estimates for soybean yield at the municipal level.

The consistency of historical data series, the location of weather stations and, fundamentally, the distance from weather stations to the place of interest are determinant factors of precision modelling for soybean grain yield estimates based on meteorological data, particularly rainfall.

This work contributes to further regional studies involving climate data, and makes evident the importance of a weather station network throughout Brazil, thus demonstrating the urgent need to increase the number of weather stations, particularly to record rainfall data.

\section{Acknowledgements}

We thank the National Council for Scientific and Technological Development (CNPq) for their financial support, and Dr. Leonardo Cesar Ferreira and MSc. Sameh Adib Abou Rafee for their contributions to the manuscript. We are also grateful to the following research institutions: Embrapa Soybean, Agronomic Institute of Paraná (IAPAR) and National Institute of Meteorology (INMET), for the meteorological data. This paper was approved for publication by the Editorial Board of Embrapa Soybean as manuscript number 302/2014.

\section{References}

ALVARES, C. A.; STAPE, J. L.; SENTELHAS, P. C.; GONÇALVES, J. L. M. Modeling monthly mean air temperature for Brazil. Theoretical and Applied Climatology, Cham, v. 110, n. 4, p. 1-23, 2012.

ALVARES, C. A.; STAPE, J. L.; SENTELHAS, P. C.; GONÇALVES, J. L. M.; SPAROVEK, G. Köppen's climate classification map for Brazil. Meteorologische Zeitschrift, Stuttgart, v. 22, n. 6, p. 711-728, 2013.

ANDRADE, G. A.; RICCE, W. S.; CARAMORI, P. H.; ZARO, G. C.; MEDINA, C. C. Zoneamento agroclimático de café robusta no Estado do Paraná e impactos das mudanças climáticas. Semina: Ciências Agrárias, Londrina, v. 33, n. 4, p. 1381-1390, 2012.

ANGULO, C.; RÖTTER, R.; TRNKA, M.; PIRTTIOJA, N.; GAISER, T.; HLAVINKA, P. Characteristic fingerprints of crop model responses to weather input data at different spatial resolutions. European Journal of Agronomy, Amsterdam, v. 49, p. 104-114, 2013.

ASHRAF, B.; YAZDANI, R.; MOUSAVI-BAYGI, M.; BANNAYAN, M. Investigation of temporal and spatial climate variability and aridity of Iran. Theoretical and Applied Climatology, Cham, v. 118, n. 1, p. 35-46, 2013.

BATTISTI, R.; SENTELHAS, P .C.; PILAU, F. G.; WOLLMANN, C. A. Eficiência climática para as culturas da soja e do trigo no estado do Rio Grande do Sul em diferentes datas de semeadura. Ciência Rural, Santa Maria, v. 43, n. 3, p. 390-396, 2013.

BRITTO, F.; BARLETTA, R.; MENDONÇA, M. Variabilidade espacial e temporal da precipitação pluvial no Rio Grande do Sul: influência do fenômeno El Niño Oscilação Sul. Revista Brasileira de Climatologia, Curitiba, v. 4, p. 37-48, 2008. 
CAMARGO, M. B. P.; BRUNINI, O.; PEDRO JÚNIOR, M. J.; BARDIN, L. Variabilidade espacial e temporal de dados termopluviométricos diários da rede de estações agrometeorológicas do Instituto Agronômico (IAC). Bragantia, Campinas, v. 64, n. 3, p. 473-483, 2005.

CARVALHO, J. R.; ASSAD, E. D.; PINTO, H. S. Interpoladores geoestatísticos na análise da distribuição espacial da precipitação anual e de sua relação com altitude. Pesquisa Agropecuária Brasileira, Brasília, v. 47, n. 9, p. 1235-1242, 2012.

CECÍlIO, R. A.; SILVA, K. R.; XAVIER, A. C.; PEZZOPANE, J. R. M. Método para a espacialização dos elementos do balanço hídrico climatológico. Pesquisa Agropecuária Brasileira, Brasília, v. 47, n. 4, p. 478-488, 2012.

COMMITTEE FOR ECONOMIC DEVELOPMENT OF AUSTRALIA - CEDA. The economics of climate change. Melbourne: CEDA, june 2014. 65 p. Available at: <https://www.ceda.com.au>. Accessed at:17 ouc. 2014.

DOORENBOS, J.; KASSAM, A. H. Efeito da água no rendimento das culturas. Campina Grande: UFPB/FAO, 1994. $306 \mathrm{p}$.

EMPRESA BRASILEIRA DE PESQUISA AGROPECUÁRIA - EMBRAPA. Tecnologias de produção de soja - região Central do Brasil 2014. Londrina: Embrapa Soja, 2013. 268 p. (Sistemas de Produção, $n^{\circ} 16$ ).

FARIAS, J. R. B.; ASSAD, E. D.; ALMEIDA, I. R.; EVANGELISTA, B. A.; LAZZAROTTO, C.; NEUMAIER, N.; NEPOMUCENO, A. L. Caracterização de risco de déficit hídrico nas regiões produtoras de soja no Brasil. Revista Brasileira de Agrometeorologia, Passo Fundo, v. 9, n. 3, p. 415-421, 2001.

FERNANDES, D. S.; HEINEMANN, A. B.; PAZ, R. L. F.; AMORIM, A. O. Calibração regional e local da equação de Hargreaves para estimativa da evapotranspiração de referência. Revista Ciência Agronômica, Fortaleza, v. 43, n. 2, p. 246-255, 2012.

GÖPFERT, H.; ROSSETTI, L. A.; SOUZA, J. Eventos generalizados e securidade agrícola. Brasília: IPEA, $1993.78 \mathrm{p}$.

MAIA, G. B. S.; ROITMAN, F. B.; CONTI, B. M. de. Instrumentos de gestão do risco agrícola: o caso do Brasil. Informativo Técnico SEAGRI, Brasília, v. 1, n. 1, p. 1-16, 2011.
MATESE, A.; CRISCI, A.; DI GENNARO, S. F.; PRIMICERIO, J.; TOMASI, D.; MARCUZZO, P.; GUIDONI, S. Spatial variability of meteorological conditions at different scales in viticulture. Agricultural and Forest Meteorology, Amsterdam, v. 189-190, p. 159167, 2014.

MONTEIRO, L. A.; SENTELHAS, P. C. Calibration and testing of an agrometeorological model for the estimation of soybean yields in different Brazilian regions. Acta Scientiarum Agronomy, Maringá, v. 36, n. 3, p. 265-272, 2014.

PEREIRA, L. M. P.; CARAMORI, P. H.; RICCE, W. S.; CAVIGLIONE, J. H. Análise comparativa de dados meteorológicos obtidos por estação convencional e automática em Londrina - PR. Semina: Ciências Agrárias, Londrina, v. 29, n. 2, p. 299-306, 2008.

SENTELHAS, P. C.; GILLESPIE, T. J.; SANTOS, E. A. Evaluation of FAO Penman-Monteith and alternative methods for estimating reference evapotranspiration with missing data in Southern Ontario, Canada. Agricultural Water Management, Amsterdam, v. 97, n. 5, p. 635-644, 2010.

SIVAKUMAR, M.; GOMMES, R.; BAIER, W. Agrometeorology and sustainable agriculture. Agricultural and Forest Meteorology, Amsterdam, v. 103, n. 1-2, p. 11-26, 2000.

SOUZA, I. D. A.; GALVANI, E.; ASSUNÇÃO, H. F. Estudo comparativo entre elementos meteorológicos monitorados por estações convencional e automática na região de Maringá, Estado do Paraná. Acta Scientiarum Technology, Maringá, v. 25, n. 2, p. 203-207, 2003.

THORNTHWAITE, C. W.; MATHER, J. R. The water balance. Centerton: Drexel Institute of Tecnology, 1955. $104 \mathrm{p}$.

TSUKAHARA, R. Y.; HIKISHIMA, M.; CANTERI, M. G. Relações entre o clima e o progresso da ferrugem asiática (Phakopsora pachyrhizi) em duas micro-regiões do Estado do Paraná. Semina: Ciências Agrárias, Londrina, v. 29, n. 1, p. 47-52, 2008.

VIANNA, M. S.; SENTELHAS, P. C. Simulação do risco de deficit hídrico em regiões de expansão do cultivo de cana-de-açúcar no Brasil. Pesquisa Agropecuária Brasileira, Brasília, v. 49, n. 4, p. 237-246, 2014.

VIVAN, G. A.; ROBAINA, A. D.; PEITER, M. X.; PARIZI, A. R. C.; BARBOZA, F. S.; SOARES, F. C. Rendimento e rentabilidade das culturas da soja, milho e feijão cultivados sob condições de sequeiro. Semina: Ciências Agrárias, Londrina, v. 36, n. 5, p. 2943-2950, 2015. 
